\title{
ESTIMATION OF APPLICABILITY OF SCATTERED RADIATION FOR XRF
}

\author{
P.Zuzaan', D.Bolortuya1, S.Davaa', A.G.Revenko² \\ ${ }^{1}$ Nuclear Research Center, National University of Mongolia \\ University street-1, Sukhbaatar District, Ulaanbaatar 210646, Mongolia \\ 2Institute of the Earth's Crust, SB RAS \\ 128 Lermontov St., 664033 Irkutsk, Russian Federation
}

Received 28 Oktober 2013

received in revised form - 18 November 2013.

\begin{abstract}
The applicability of coherently and incoherently scattered radiation was investigated on the example of quantifying the $\mathrm{Nb}$ content in wolframite. The calculated and experimental intensities of $\mathrm{Nb} K_{\alpha}$-line for binary and multicomponent mixtures of $\mathrm{Nb}_{2} \mathrm{O}_{5}$ with various matrices have been compared. The major oxides $\mathrm{MgO}, \mathrm{SiO}_{2}, \mathrm{CaO}, \mathrm{Fe}_{2} \mathrm{O}_{3}$, and a typical component of tungsten ore $(\mathrm{Fe}, \mathrm{Mn}) \mathrm{WO}_{3}$ were used as the main matrices. Measurements were carried out using the energy dispersive X-ray spectrometer with $\mathrm{Si}(\mathrm{Li})$-detector and radioactive isotope source ${ }^{109} \mathrm{Cd}$. The analysis of data shows that when using the ratio of the intensities of coherently and incoherently scattered X-radiation of the excitation source the dependence of the analytical line intensity of niobium on the content of $W$ in the samples is taken into account. The experimental results confirm the conclusions of the theoretical consideration. This technique was successfully used to study wolframite samples from the deposits of the Eastern and Western Mongolia.

A procedure for the determination of $\mathrm{Cu}, \mathrm{Mo}$ and Fe concentrations in ores, copper and molybdenum concentrates, and enrichment waste was developed to control the process of enrichment at the mining company "Erdenet", Mongolia. This procedure was based on using regression equations. The form of regression equations was chosen based on the theoretically calculated intensities. The comparison results of measurements using the newly developed technique and the standard-background method are presented.

Keywords: X-ray spectral fluorescence analysis of ores and enrichment products, method of standard-background, theoretical simulation of matrix effects.
\end{abstract}

Purev Zuzaan - Doctor of Physics and Mathematics, Professor, Head of the division of nuclear-physical methods of analysis at the Nuclear research center, the National University of Mongolia.

Field of Research: the interaction of radiation with matter, X-ray fluorescence analysis.

Published over 250 papers.

Damdinsuren Bolortuya - magister, scientific researcher, Nuclear research center, the National University of Mongolia.

Field of Research: X-ray fluorescence analysis of natural materials.

Published over 30 papers.

Suren Davaa - PhD in physics, Professor, Director of Nuclear research center, the National University of Mongolia.

Field of research: nuclear spectroscopy, X-Ray fluorescence analysis.

Published about 100 scientific papers.

Anatoly Grigorievich Revenko - Doctor of technical sciences, Chief of Analytical Center at the Institute of the Earth's Crust of Siberian Branch of the Russian Academy of Sciences.

Field of research: physics of X-rays; X-ray spectral fluorescence analysis of rocks, soils, sediments, ores, cultural heritage materials.

Published over 300 papers

\section{INTRODUCTION}

The study of the distribution of impurity elements in the ore minerals allows to reveal a number of regularities of mineralization. For wolframite deposits tantalum, niobium, and scandium are of particular interest from this point of view. It was found that in some cases the wolframites can be an additional source of niobium, tantalum, and scandium [1, 2]. It was also found that the content of these impurity elements and their ratios can inform about the conditions of formation of wolframite deposits. On the other hand, the chemical methods for the separation and determination of $\mathrm{Ta}$ and $\mathrm{Nb}$ in wolframites are laborious. 
X-ray fluorescence method is now widely used for the determination of many trace elements, as well high content elements in rocks. However, this method as the most other methods is under the influence of interfering elements on the accuracy when determining an analyte. There are some ways to eliminate the matrix effects $[3,4]$. In spite of several advantages, none of these methods is universal.

We have investigated the applicability of different versions of the background standard method to determine contents of some elements in the geological samples, in particular, niobium in wolframites and molybdenum in Mo-concentrates.

\section{RESULTS}

\section{Determination of $\mathrm{Nb}$ in wolframite}

The application of standard-background method allows to significantly reduce the influence of matrix

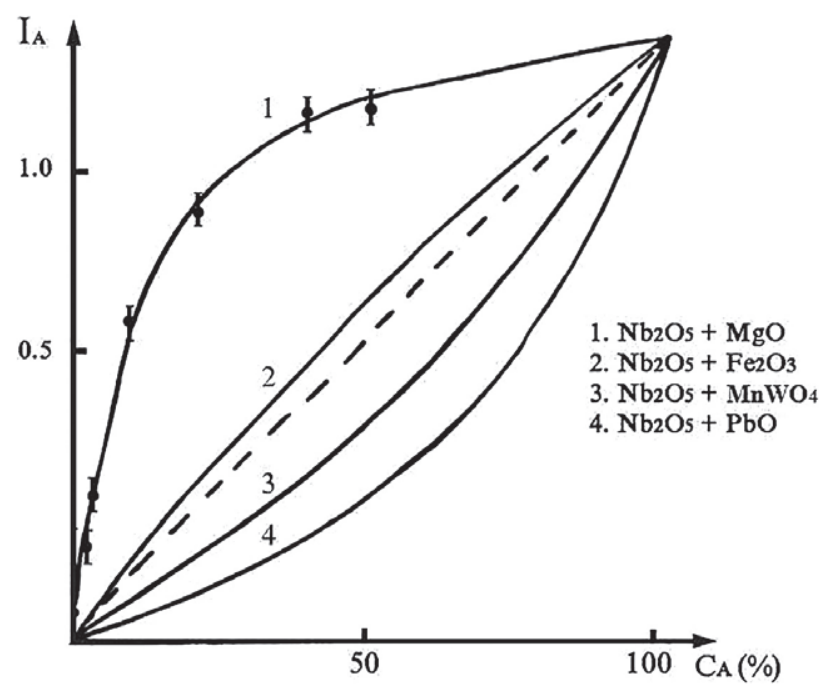

Fig. 1. Dependence of $\mathrm{NbK}_{\alpha}$ intensities on $\mathrm{Nb}$ concentration in the different matrices: (1) curve for the case where the absorption of the matrix is less than the absorption of $\mathrm{Nb},(2)$ and (3) curves correspond to the similar absorption of the matrix and $\mathrm{Nb}$, (4) curve for the case where the absorption of the matrix is greater than $\mathrm{Nb}$ effects on analytical results [3,5-7]. To reduce or eliminate the influence of matrix effects on results of X-ray fluorescence analysis (XRF) the applicability of coherently and incoherently scattered radiation was investigated on the example of quantifying the $\mathrm{Nb}$ content in wolframite. We have compared the calculated and experimental intensities of $\mathrm{NbK}_{\alpha}$-line $(16.7 \mathrm{keV})$ for binary and multicomponent mixtures of $\mathrm{Nb}_{2} \mathrm{O}_{5}$ with various matrices. The major oxides $\mathrm{MgO}, \mathrm{SiO}_{2}, \mathrm{CaO}, \mathrm{Fe}_{2} \mathrm{O}_{3}$, and a typical component of tungsten ore $(\mathrm{Fe}, \mathrm{Mn}) \mathrm{WO}_{3}$ were used as the main matrices.

The intensities of radiation incoherently scattered from the sample were calculated from the eq. (1):

$$
I_{\text {incoh }}=K_{p} I_{0}+\frac{\sigma_{\text {incoh }}}{\mu_{1}+n \cdot \mu_{m \sigma_{\text {incoh }}}},
$$

the intensities of coherently scattered radiation were calculated according to the formula:

$$
I_{\text {coh }}=K_{p} I_{0} \frac{\sigma_{c o h}}{2 \mu_{1}}
$$

where $I_{0}$ is intensity of primary radiation, $\sigma_{\text {incoh }}$ and $\sigma_{\text {coh }}$ are mass scattering coefficients of radiation coherently and incoherently scattered from sample, respectively, $E_{0}$ is energy of primary radiation, $\mu_{\mathrm{m} 1}$ and $\mu_{\text {mincoh }}$ are mass absorption coefficients of incident radiation and radiation scattered from sample, respectively, $K_{p}$ is constant. The mass absorption coefficients were calculated using the data from [8], and mass scattering coefficients were taken from [9].

The intensities of radiation source coherently and incoherently scattered from sample, and their ratio were taken as analytical parameters. The calculated values of the fluorescence intensities $I_{A}$, as well $I_{\text {coh }}$ and $I_{\text {incoh }}$ for $\mathrm{AgK} \alpha \alpha$ line and their ratios for binary samples are shown in Table 1. You can see from the considered example of the obtained data that alterations of $I_{\text {incon }}$ and $I_{A}$ are similar and alteration of $I_{\text {con }}$ is much less.

The mass absorption coefficients of the considering oxides for $\mathrm{NbK \alpha}$ - line have changed in the wide range. As a result, the dependence between intensity and concentration is significantly different for separate binary

Table 1

Calculated value of $I_{A}, l_{\text {coh }}, l_{\text {incoh }}$ and their ratio of $\mathrm{NbK}_{\alpha}$-line for the binary samples

\begin{tabular}{|c|c|c|c|c|c|c|c|c|}
\hline $\begin{array}{c}\mathrm{Nb}_{2} \mathrm{O}_{5}, \\
\%\end{array}$ & Matrix & $I_{\mathrm{A}}$ & $I_{\text {coh }}$ & $I_{\text {incoh }}$ & $I_{\mathrm{A}} / I_{\text {coh }}$ & $I_{\mathrm{A}} / I_{\text {incoh }}$ & $R_{\mathrm{A}}=I_{\text {incoh }} / I_{\text {coh }}$ & $I_{\mathrm{A}} / R_{\mathrm{A}}$ \\
\hline \multirow{6}{*}{0.1} & $\mathrm{MgO}$ & 1.04 & 5.91 & 31.8 & 0.176 & 0.033 & 5.38 & 0.19 \\
\cline { 2 - 9 } & $\mathrm{SiO}_{2}$ & 0.84 & 5.38 & 26.5 & 0.16 & 0.032 & 4.92 & 0.17 \\
\cline { 2 - 9 } & $\mathrm{CaO}$ & 0.24 & 2.67 & 6.62 & 0.09 & 0.036 & 2.48 & 0.10 \\
\cline { 2 - 9 } & $\mathrm{Fe}_{2} \mathrm{O}_{3}$ & 0.127 & 1.98 & 3.32 & 0.06 & 0.038 & 1.68 & 0.08 \\
\cline { 2 - 8 } & $\mathrm{MnWO}_{3}$ & 0.052 & 2.41 & 0.99 & 0.022 & 0.053 & 0.41 & 0.13 \\
\hline \multirow{4}{*}{10} & $\mathrm{MgO}^{3}$ & 53.6 & 2.32 & 9.30 & 23.1 & 5.76 & 4.01 & 13.4 \\
\cline { 2 - 8 } & $\mathrm{SiO}_{2}$ & 48.4 & 2.34 & 8.82 & 20.7 & 5.49 & 3.77 & 12.8 \\
\cline { 2 - 8 } & $\mathrm{CaO}$ & 21.1 & 2.04 & 4.55 & 10.3 & 4.63 & 2.23 & 9.4 \\
\cline { 2 - 8 } & $\mathrm{Fe}_{2} \mathrm{O}_{3}$ & 12.4 & 1.73 & 2.76 & 7.14 & 4.47 & 1.60 & 7.7 \\
\cline { 2 - 8 } & $\mathrm{MnW}_{3}$ & 5.5 & 2.26 & 1.00 & 2.42 & 5.47 & 0.44 & 12.4 \\
\hline
\end{tabular}


Calculated and experimental values of $I_{\mathrm{Nb},} I_{\text {coh, }} I_{\text {incoh }}$ and their ratios for $\mathrm{Nb} K_{\alpha}$-line in multicomponent samples

\begin{tabular}{|c|c|c|c|c|c|c|c|c|c|c|c|c|c|c|c|c|}
\hline \multicolumn{5}{|c|}{ Oxide concentrations, \% } & \multicolumn{2}{|c|}{$I_{N b}$} & \multicolumn{2}{|c|}{$I_{\text {incoh }}$} & \multicolumn{2}{|c|}{$I_{\text {coh }}$} & \multicolumn{2}{|c|}{$R=I_{\mathrm{i}} / I_{\text {coh }}$} & \multicolumn{2}{|c|}{$I_{\mathrm{Nb}} / R$} & \multicolumn{2}{|c|}{$I_{\mathrm{Nb}} / I_{\text {incoh }}$} \\
\hline $\mathrm{Nb}_{2} \mathrm{O}_{5}$ & $\mathrm{MnO}_{2}$ & $\mathrm{Fe}_{2} \mathrm{O}_{3}$ & $\mathrm{WO}_{3}$ & $\mathrm{SiO}_{2}$ & 1 & 2 & 1 & 2 & 1 & 2 & 1 & 2 & 1 & 2 & 1 & 2 \\
\hline \multirow{5}{*}{1.0} & \multirow{5}{*}{15.0} & \multirow{5}{*}{8.0} & 30 & 46 & 1.000 & 1.000 & 1.000 & 1.000 & 1.000 & 1.000 & 1.000 & 1.000 & 1.000 & 1.000 & 1.000 & 1.000 \\
\hline & & & 40 & 36 & 0.798 & 0.791 & 0.763 & 0.786 & 0.970 & 0.989 & 0.787 & 0.795 & 1.014 & 0.995 & 1.049 & 1.006 \\
\hline & & & 50 & 26 & 0.644 & 0.691 & 0.604 & 0.681 & 0.950 & 0.975 & 0.636 & 0.699 & 1.013 & 0.989 & 1.066 & 1.015 \\
\hline & & & 60 & 16 & 0.573 & 0.545 & 0.492 & 0.530 & 0.937 & 0.967 & 0.526 & 0.548 & 1.089 & 0.995 & 1.165 & 1.028 \\
\hline & & & 70 & 6 & 0.497 & 0.485 & 0.408 & 0.467 & 0.927 & 0.957 & 0.441 & 0.488 & 1.127 & 0.994 & 1.218 & 1.039 \\
\hline
\end{tabular}

Comment: 1 - calculated and 2 - experimental values.

systems. The relationship between $\mathrm{NbK \alpha}$ intensity and $\mathrm{Nb}$ concentration is shown in Fig. 1. The solid line corresponds to calculated data and points are experimental values. Measurements were carried out using the energy dispersive X-ray spectrometer with $\mathrm{Si}(\mathrm{Li})$ detector and radioactive isotope source $\mathrm{Cd}-109$ during $200 \mathrm{~s}$. The Figure shows good agreement between calculated and experimental data.

Table 2 presents the calculated and experimental data for multicomponent mixture samples which simulate the composition of the tungsten ore. The samples studied contain $\mathrm{Nb}_{2} \mathrm{O}_{5}(1 \%), \mathrm{MnO}(15 \%), \mathrm{Fe}_{2} \mathrm{O}_{3}(8 \%)$, and the tungsten concentration changes depending on the content of $\mathrm{SiO}_{2}$.

As Table 2 shows, the specific intensity of the analytical line of $\mathrm{Nb}$ greatly varies with change in the tungsten concentration at a constant total concentration of $\mathrm{Mn}$ and $\mathrm{Fe}$. When changing the tungsten concentration from 30 to $70 \%$ the niobium intensity varies more than twice. As can be seen from Table 1 the account for the matrix effects using the coherently and incoherently scattered radiation allows to significantly reduce the uncertainty in determining the niobium concentration. The analysis of data presented in Table 2 shows that the ratio of the intensities of coherently and incoherently scattered X-radiation of the excitation source takes well into account the dependence of the intensity of the analytical niobium line on the content of $W$ in the samples. The authors of a number of papers have attempted to explain the applicability of this approach in different analytical situations. A review of these papers can be found in [10]. The experimental results generally confirm the conclusions of the theoretical consideration.

The results of calculation and experiment showed:

The intensity of coherently scattered radiation is less sensitive to the change in a chemical composition of sample than the fluorescence intensity. In case of significant changes in the chemical composition of sample the application of ratio of coherently scattered radiation and the intensity of fluorescence does not provide the acceptable analytical precision when determining $\mathrm{Nb}$ concentration;

However, the intensity of incoherently scattered radiation changes similarly to the fluorescence radiation for elements whose absorption edge energies do not exceed the energy peaks of analytical lines. The difference between normalized intensities significantly decreases when sample consists of elements with low $Z$ and elements with high $Z$ for different matrices;

The use of dividing the fluorescence intensities by the ratio of coherently and incoherently scattered radiation intensities $R=I_{\text {incon }} / I_{\text {con }}$ provides the satisfactory accuracy of analysis. In this case the concentration has to be calculated by simple formula the intensities of coherently scattered radiation were calculated according to the formula:

$$
C_{A}=\frac{I_{A}}{I_{s t}} \cdot \frac{R_{s t}}{R_{A}} \cdot C_{s t},
$$

where $I_{\mathrm{A}}$ and $I_{\text {st }}$ are intensities of analytical lines for the determining elements in samples analysed and certified reference materials, respectively; $R_{\mathrm{st}}$ and $R_{\mathrm{A}}$ are ratios of coherently and incoherently scattered radiation for analysed samples and certified reference materials; $C_{\mathrm{st}}$ is concentration of element in CRM.

The study has shown that an uncertainty of $\mathrm{Nb}$ determination in wolframite samples by this method is less than $5 \%$. In order to obtain the better precision of the determination of $\mathrm{Nb}$ concentration it is necessary to take account of the dependence of analytical parameters on the concentration of $\mathrm{W}$ in sample.

The experimental test was performed for the set of wolframite samples of known chemical composition and certified reference materials SVT [11]. The concentration of $\mathrm{Nb}$ determined by standard-background method (ratio of coherently and incoherently scattered radiation) is shown in Table 3. XRF results give good agreement with certified data, although the chemical composition of the certified reference materials SVT varies within the wide

Table 3

Results of XRF determination of $\mathrm{Nb}_{2} \mathrm{O}_{5}$ in standard reference materials, \%

\begin{tabular}{|c|c|c|}
\hline CRM & Certified value* & $\begin{array}{c}\text { Concentration obtained } \\
\text { by formula (3) }\end{array}$ \\
\hline SVT -5 & $0.0134 \pm 0.0005$ & $0.0130 \pm 0.0007$ \\
\hline SVT -6 & $0.110 \pm 0.005$ & $0.108 \pm 0.004$ \\
\hline SVT -8 & $1.06 \pm 0.06$ & $1.00 \pm 0.0052$ \\
\hline SVT -12 & $0.100 \pm 0.004$ & $0.100 \pm 0.004$ \\
\hline SVT -13 & $0.013 \pm 0.0005$ & $0.014 \pm 0.001$ \\
\hline SVT -7 & $0.0070 \pm 0.0005$ & $0.0078 \pm 0.0007$ \\
\hline SVT -9 & $2.03 \pm 0.04$ & $1.95 \pm 0.06$ \\
\hline
\end{tabular}

Comment: ${ }^{*}$-the confidence intervals are calculated using the conventional formula from [13]. 
Table 4

The variation in chemical composition of the industry products

\begin{tabular}{|c|c|c|c|c|}
\hline \multirow{2}{*}{ Product } & \multicolumn{4}{|c|}{ Concentration, \% } \\
\cline { 2 - 5 } & $\mathrm{Cu}$ & Mo & $\mathrm{Fe}$ & $\begin{array}{c}\text { Density } \\
\text { of pulp } \\
\text { (flow) }\end{array}$ \\
\hline Ore & $0.3-1.7$ & $0.006-0.08$ & $1-6$ & $18-35$ \\
\hline Waste & $0.04-0.3$ & $0.002-0.04$ & $0.5-5$ & $7-35$ \\
\hline $\begin{array}{c}\text { Concen- } \\
\text { trate of Cu }\end{array}$ & $20-40$ & $0.04-0.8$ & $10-40$ & $15-50$ \\
\hline $\begin{array}{c}\text { Concen- } \\
\text { trate of Mo }\end{array}$ & $0.4-3.0$ & $40-55$ & $0.5-5$ & - \\
\hline $\begin{array}{c}\text { Joint con- } \\
\text { centrate }\end{array}$ & $5-18$ & $0.05-0.5$ & $15-35$ & $15-40$ \\
\hline
\end{tabular}

range and is very different from the composition of the certified reference materials used. We have successfully used this technique to study wolframite samples from the deposits of the Eastern and Western Mongolia.

\section{Determination of Mo in molybdenum concentrate}

To develop new XRF techniques for any substance it is necessary to obtain the information about the ranges of the chemical sample compositions and choose a certain means to eliminate their influence on the analysis results. In addition, a mathematical correction could be used for accounting matrix effects. Nowadays this approach is widely used in practice.

The calculation of matrix effects is the important step in the development of the X-ray fluorescence methods. To control the process of enrichment at the mining company "Erdenet", Mongolia, it is necessary to determine Cu, Mo and Fe. The effect of chemical composition on the intensities of the $\mathrm{CuK}_{\alpha}-$, MoK${ }_{\alpha}$, and $\mathrm{FeK}_{\alpha}$-lines was studied for ores, copper and molybdenum concentrates, and enrichment waste [12].

As Table 4 shows, concentrations of elements vary over a wide range for each product. In particular, there are the most significant changes in the Cu contents in copper concentrate and Mo in molybdenum concentrate (up to $10 \%$ abs. or more). All products contain iron (from 1 to $40 \%$ abs.). The concentration of Mo in tailing dump is close to the detection limit ( $n \cdot 0.001 \%$ abs). The detection limit was calculated according to the common used formula from [5]. As a result, the matrix effects can occur in determining $\mathrm{Cu}$, Mo and $\mathrm{Fe}$ in ore and $\mathrm{Cu}$ and Mo in concentrates.

The calculation of matrix effects was performed using the theoretical intensity. These effects were estimated using the intensities of analytical lines excited by the polychromatic primary beam by the formula, which takes into account the effects of enhancement and absorption. The excitation effect of the third order has not taken into account because its contribution is negligible for the considered case.

For these calculations the contents of $\mathrm{Cu}$, Mo and Fe were taken according to the chemical analysis, and concentrations of $S$ and other elements were given based on contents of reference samples of the same type of products. The following conditions of excitation were used for the calculations: potential is $40 \mathrm{kV}$, Rh anode, thickness of Be window of X-ray tube is 200 microns and the angles of incidence of the primary and take-off of fluorescence radiation are $90^{\circ}$ and $45^{\circ}$, respectively.

The absorption effects were mostly occurred when analysing enrichment waste and ore liquid mix. The change in the interfering element concentrations by $1 \%$ in these products leads to the significant change in the intensity of analytical lines of the detemining elements. Table 5 presents the values of the influence coefficients of major rock-forming elements, as well S, Cu and Mo for $\mathrm{FeK}_{\alpha}, \mathrm{CuK}_{\alpha}$, and $\mathrm{MoK}_{\alpha}$ analytical lines. The coefficients characterize the change in fluorescence intensity $(\%$ rel.) for the particular analytical line when changing the concentration of the influencing element by $1 \%$ abs. [5]. This change was due to the change in $\mathrm{SiO}_{2}$ content in the sample. The calculation is performed for the reference samples of $\mathrm{Cu}$ concentrate and $\mathrm{Cu}-\mathrm{Mo}$ ores.

The contents of $\mathrm{S}, \mathrm{TiO}_{2}, \mathrm{Fe}_{2} \mathrm{O}_{3}$, and Mo have a great influence on the intensity of $\mathrm{CuK}_{\alpha}$-line. For example, in the ore with increasing the $\mathrm{CaO}$ content by $1 \%$ the intensity of $\mathrm{CuK}_{\alpha}$ decreases by $1.78 \%$, while at a similar change in the concentration of $\mathrm{Fe}_{2} \mathrm{O}_{3}$ the intensity of $\mathrm{CuK}_{\alpha}$ decreases by $3.49 \%$. For $K_{\alpha}$ of Mo and Fe the same situation takes place.

To estimate the effect of the chemical composition of the samples on the XRF results using the external standard method we have plotted the theoretically calculated

Table 5

Influence factors of major rock-forming elements on intensities of analytical lines of the determining elements

\begin{tabular}{|c|c|c|c|c|c|c|}
\hline \multirow{2}{*}{$\begin{array}{c}\text { Influence } \\
\text { component }\end{array}$} & \multicolumn{3}{|c|}{ Copper concentrate } & \multicolumn{2}{c|}{ Ore } \\
\cline { 2 - 7 } & $\mathrm{Fe}$ & $\mathrm{Cu}$ & $\mathrm{Mo}$ & $\mathrm{Fe}$ & $\mathrm{Cu}$ & $\mathrm{Mo}$ \\
\hline $\mathrm{Al}_{2} \mathrm{O}_{3}$ & 0.07 & 0.04 & 0.01 & 0.11 & 0.09 & 0.09 \\
\hline $\mathrm{S}$ & -0.9 & -0.44 & -0.22 & -1.29 & -1.78 & -1.05 \\
\hline $\mathrm{CaO}$ & -1.34 & -0.7 & -0.38 & -1.97 & -1.78 & -1.76 \\
\hline $\mathrm{TiO}_{2}$ & -1.31 & -0.7 & -0.4 & -2.01 & -1.86 & -1.96 \\
\hline $\mathrm{Fe}_{2} \mathrm{O}_{3}$ & - & -1.4 & -0.8 & - & -3.49 & -3.86 \\
\hline $\mathrm{Cu}$ & 0 & - & -1.68 & 0.56 & - & -7.45 \\
\hline $\mathrm{Mo}$ & -1.58 & -0.59 & - & -1.86 & -1.13 & - \\
\hline
\end{tabular}


intensities of analytical lines $I_{21}$ versus the element concentration in the samples (Fig. 2). These dependencies were linear, except for Mo (Fig. 2, d). However, the ratio of the measured Mo intensity to the intensity of scattered radiation has a linear dependence on the Mo concentration in molybdenum concentrate (Fig. 3) The dispersion of points around the calibration line is due to the influence of chemical composition of sample matrices on the fluorescence intensity and characterizes the uncertainty in results of the analysis when using the method of external standard. The value of influencing factors depends on excitation conditions (anode material, Be window thickness of X-ray tube and geometry of spectrometer) and the chemical composition of the sample analysed.

When significant varying the sample composition (if there are several $\mathrm{CRMs}$ ) the concentration of the element determined can be obtained with the sufficient accuracy using regression equations. The form of regression equations was chosen based on the theoretically calculated intensities.

To select optimal regression
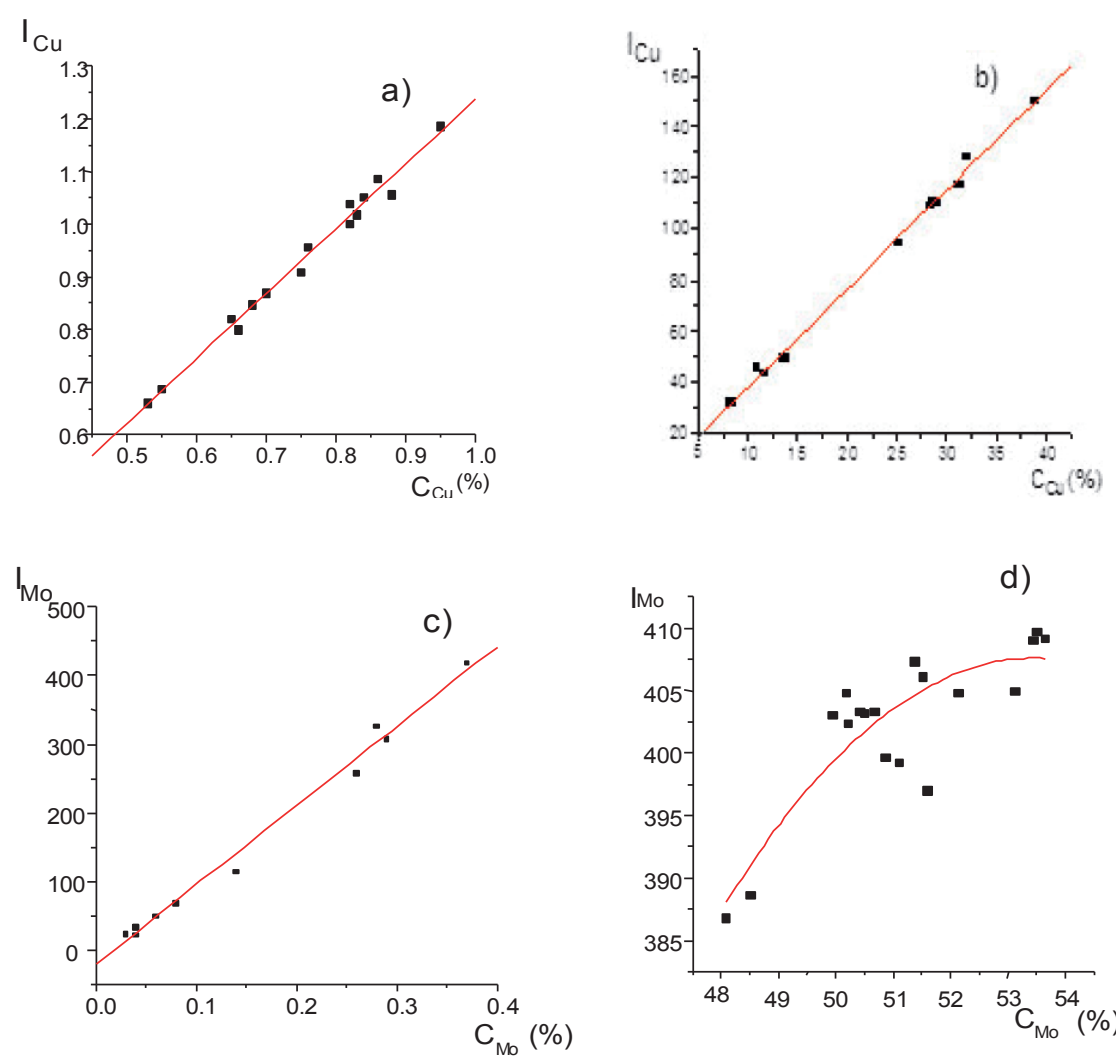

Fig. 2. Dependence of intensities of analytical lines on the concentrations of determining elements: Cu in ore; b) Cu in copper concentrate; c) Mo in ore; d) Mo in molybdenum concentrate

equations and to determine calibration

characteristics, experimental data of intensities obtained from measurements of over the twenty samples of each product were used. The following equations were considered for all products:

$$
\begin{gathered}
C_{i}=a_{0 i}+a_{1 i} R_{i}+R_{i} \sum_{j=4}^{6} a_{j i} R_{j}, \\
C_{i}=a_{0 i}+\sum_{j=1}^{n} a_{j i} R_{j} \quad \text { and } \\
C_{i}=a_{0 i}+a_{1 i} R_{i},
\end{gathered}
$$

where $R_{i}=J_{i} \frac{J_{2 i}^{0}}{J_{2 i}}$ and $R_{j}=J_{j} \frac{J_{2 j}^{0}}{J_{2 j}}$ are corrected intensities of analysed and intefering elements, respectively. Samples with known elemental contents are used for the determination of equation coefficients. The analytical results of specialized chemical laboratory at the Erdenet Corporation were used too. The results calculated from these equations show that the residual uncertainties do not exceed the acceptable values. The best accuracy is provided by equation (4) and (5) when contents of elements in analyzed samples change within a wide range. The application of equation (6) also gives results with good accuracy if the chemical composition varies over relatively narrow ranges.

Table 6 presents the comparative results of measurements using the new developed technique,

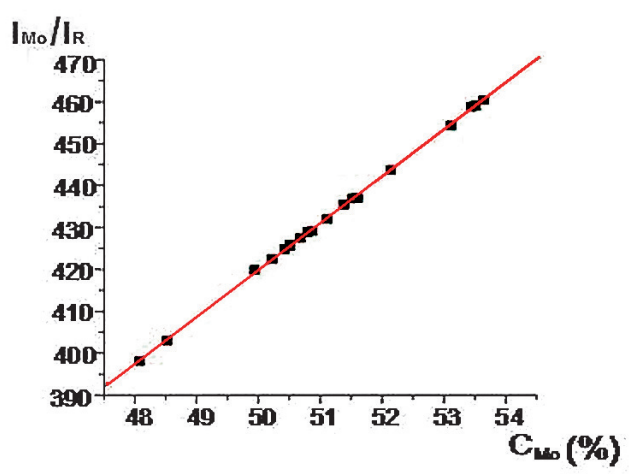

Fig. 3. Dependence of corrected analytical line intensities of molybdenum on its concentrations

calculations by equation (5) and the method of standardbackground. Hence it can be seen that the residual uncertainty in determination of those contents by selected equations do not exceed the tolerances.

\section{SUMMARY}

The applicability of intensities of coherently and incoherently scattered radiation from the source as an analytical parameter, as well the ratios of these intensities are considered. It is shown that the ratio of the intensities of the coherent and Compton scattered radiation takes into fuller account the influence of the chemical composition of samples in a number of cases. The combined method is considered for determining element contents in samples with a wide range of concentrations, based on the application of the standard background 
Table 6

Comparative results of measurements used developed new technique and a method of standard-background, \%

\begin{tabular}{|c|c|c|c|c|c|c|c|c|c|c|c|c|}
\hline \multirow{2}{*}{$\begin{array}{c}\text { Ele- } \\
\text { ment }\end{array}$} & \multicolumn{3}{|c|}{ Copper concentrate } & \multicolumn{3}{|c|}{ Molibdenum concentrate } & \multicolumn{3}{|c|}{ Ore } & \multicolumn{3}{|c|}{ Tailings dump } \\
\hline & $A$ & $B$ & tol & $A$ & $B$ & tol & $A$ & $B$ & tol & $A$ & $B$ & tol \\
\hline $\mathrm{Cu}$ & 0.44 & 0.71 & 0.6 & 0.065 & 0.065 & 0.12 & 0.032 & 0.051 & 0.04 & 0.009 & 0.011 & 0.02 \\
\hline Mo & 0.017 & 00.015 & 0.02 & 0.57 & 0.85 & 0.7 & 0.002 & 0.003 & 0.003 & 0.002 & 0.002 & 0.002 \\
\hline $\mathrm{Fe}$ & 0.70 & 0.84 & 0.7 & 0.29 & 0.29 & 0.3 & 0.11 & 0.26 & 0.3 & 0.15 & 0.17 & 0.2 \\
\hline
\end{tabular}

Comments: A - new method, B - old method, tol - tolerances.

method and the regression equations. The conducted investigations have allowed to develop a method for the determination of niobium in wolframites, as well molybdenum, copper, and iron in the industrial products, namely products of ore processing (when determining contents of low $Z$ elements in the matrices with high $Z$ or high contents of elements).

\section{REFERENCES}

1. Chetyrbotskaya N.I. Volframit kak indikator i novyi istochnik tantalovogo syr'ya [Wolframite as an indicator and a new source of tantalum raw materials]. Moscow, Nedra, 1972. 132 p. (in Russian).

2. Ivanov G.F., Maksimyuk I.E. [Tantalum and niobium in Mongolian wolframites]. Geologiya rudnykh mestorozhdenii [Mining geology], 1972, vol. 14, no. 2, pp. 67-77 (in Russian). 3. Losev N.F. Kolichestvennyi rentgenospectral'nyi fluorestsentnyi metod analiza [Quantitative X-ray spectral fluorescent method of analysis]. Moscow, Nauka, 1969. 336 p. (in Russian).

4. Plotnikov R.I., Pshenichnyi G.A. Fluorestsentnyi rentgenoradiometricheskii analiz [X-ray fluorescent radiometric analysis]. Moscow, Atomizdat, 1973. 264 p. (in Russian).

5. Revenko A.G. Rentgenospectral'nyi fluorestsentnyi analiz prirodnykh materialov [X-Ray Spectral Fluorescence Analysis of Natural Materials]. Novosibirsk, Nauka, 1994. 264 p. (in Russian).

6. Zuzaan P., Gansukh N., Bolortuya D. Radionuclide induced energy dispersive $\mathrm{X}$-ray fluorescence for the determination of $\mathrm{La}, \mathrm{Ce}, \mathrm{Pr}$ and $\mathrm{Nd}$ and their content sums in the rare-earth ores. X-Ray Spectrometry, 2010, vol. 39, no. 1, pp. 52-56. doi: $10.1002 / x r s .1221$

7. Cherkashina T.Yu., Khudonogova E.V., Revenko A.G., Letnikova E.F. Application of the background standard method for the determination of $\mathrm{Rb}, \mathrm{Sr}, \mathrm{Y}, \mathrm{Zr}$, and $\mathrm{Nb}$ contents in phosphorites by X-ray fluorescence. $X$-Ray Spectrometry, 2009, vol. 38, no. 2, pp. 144-151. doi: 10.1002/xrs.1122.

8. Heinrich K.F.J. The electron microprobe. Chapter "X-Ray absorption uncertainty". New York, Wiley, 1966, pp. 291-377. 9. Bakhtiarov A.V., Chernoberejskaya S.A. [The coefficients of X-ray scattering]. Apparatura i Metody Rentgenovskogo Analiza [Equipment and methods of X-ray analysis], Leningrad, 1972, vol. 11, pp. 200-218 (in Russian).

10. Tsvetyansky A.L. Uchet vliyaniya neizmeryaemykh komponentov i trudno kontroliruemykh faktorov na rezultaty rentgenofluorestsentnogo analyza Avtoref. dissertatsii dokt. fiz.-mat. nauk [Accounting for the effect of unmeasured components and unmanageable factors on the XRF results. Author's abstract of dr. phys. and math. sci. diss.]. Rostovon-Don, 2010. 40 p. (in Russian).

11. Lontsikh S.V., Petrov L.L. Standartnye obraztsy sostava prirodnykh sred [CRMs of Environment Contents]. Novosibirsk, Nauka, 1988. 277 p. (in Russian).
12. Zuzaan P., Gansukh N., Davaa S., Damdinsuren Z., Delgerbat L., Rinchinzhugder T. About an improvement of the X-ray analysis method for the process control at the ore mining and processing enterprise «Erdenet». Uchenye zapiski MonGU [Scientific Transactions, National University of Mongolia], 2000, vol. 159, no. 7, pp. 168-176 (in Mongolian). 13. Losev N.F., Smagunova A.N. Osnovy rentgenospektral'nogo fluorestsentnogo analiza [Fundamentals of X-ray fluorescence analysis]. Moscow, Khimiya, 1982. 282 p. (in Russian).

\section{ЛИТЕРАТУРА}

1. Четырбоцкая Н.И. Вольфрамит как индикатор и новый источник танталового сырья. М.: Недра, 1972. 132 с. 2. Иванов Г.Ф., Максимюк И.Е. Тантал и ниобий в вольфрамитах Монголии // Геология рудных месторождений. 1972. T. 14, № 2. С. 67-77.

3. Лосев Н.Ф. Количественный рентгеноспектральный фллуоресцентный метод анализа. М.: Наука, 1969. 336 с. 4. Плотников Р.И., Пшеничный Г.А. Флуоресцентный рентгенорадиометрический анализ. М.: Атомиздат, 1973. 264 с. 5. Ревенко А.Г. Рентгеноспектральный флуоресцентный анализ природных материалов. Новосибирск: Наука, 1994. 264 с.

6. Zuzaan P., Gansukh N., Bolortuya D. Radionuclide induced energy dispersive $\mathrm{X}$-ray fluorescence for the determination of $\mathrm{La}, \mathrm{Ce}, \mathrm{Pr}$ and $\mathrm{Nd}$ and their content sums in the rare-earth ores // X-Ray Spectrometry. 2010. V. 39, no. 1. P. 52-56.

7. Cherkashina T.Yu., Khudonogova E.V., Revenko A.G., Letnikova E.F. Application of the background standard method for the determination of $\mathrm{Rb}, \mathrm{Sr}, \mathrm{Y}, \mathrm{Zr}$, and $\mathrm{Nb}$ contents in phosphorites by X-ray fluorescence // X-Ray Spectrometry. 2009. V. 38, no. 2. P. 144-151.

8. Heinrich K.F.J. The electron microprobe. Chapter "X-Ray absorption uncertainty”. New York: Wiley, 1966. P. 291-377. 9. Бахтияров А.В., Чернобережская С.А. Коэффрициенты рассеяния рентгеновских лучей // Сб. статей «Аппаратура и методы рентгеновского анализа». 1972. Вып. 11. С. 200-218. 10. Цветянский А.Л. Учёт влияния неизмеряемых компонентов и трудноконтролируемых факторов на результаты рентгенофлуоресцентного аналита. Автореф. дис. ... д-ра физ.-мат. наук. Ростов-на-Дону, 2010. 40 с.

11. Лонцих С.В., Петров Л.Л. Стандартные образцы состава природных сред. Новосибирск: Наука, 1988. 277 с. 12. Zuzaan P., Gansukh N., Davaa S., Damdinsuren Z., Delgerbat L., Rinchinzhugder T. About an improvement of the X-ray analysis method for the process control at the ore mining and processing enterprise "Erdenet" // Scientific Transactions, National University of Mongolia, 2000. V. 159, no. 7. P. $168-176$ (in Mongolian).

13. Лосев Н.Ф., Смагунова А.Н. Основы рентгеноспектрального фрлуоресцентного анализа. М.: Химия, 1982. 282 с. 